\title{
南秦岭造山带“大堡组”中晚古生代化石的发现及其 意义
}

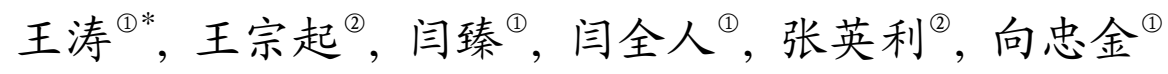

(1) 中国地质科学院地质研究所, 北京 100053 ;

(2) 中国地质科学院矿产地质研究所, 北京 100053

*E-mail: real-wt@sohu.com

收稿日期: 2009-10-27; 接受日期: 2010-10-22

国家自然科学基金(批准号: 40602026, 40772137)、中国地质科学院地质研究所所长基金(编号: J0720)、中国地质调查局地质调查项目(编 号: 1212010611807, 1212010711807)和国家科技支撑计划课题(编号: 2006BAB01A11)资助

摘要南秦岭“大堡组”早期被认为属于奥陶纪地层. 经过详细的野外地质工作, 查明“大 堡组”由灰-深灰色的泥岩和粉砂岩以及裹于其间的灰岩、硅质岩、火山岩和凝灰岩块体组成. 在灰岩块体中新发现了中泥盆世的牙形石和珊瑚等化石，表明“大堡组”形成时代应为晚古 生代. 因此，结合现有的资料推断南秦岭“大堡组”为晚古生代或早中生代形成的增生混杂 带.

关键词

南秦岭造山带

“大堡组”

中泥盆世

珊瑚

牙形石
秦岭造山带的结构、造山过程和动力学研究已取 得了丰硕的成果, 但是一些基础性的问题还存在较 大的分歧. 特别是对南秦岭 “白水江群”的构造岩石 组合不清楚, 导致在“白水江群”的形成时代和构造 属性上存在着两种不同的观点: 一是早古生代扬子 被动大陆边缘 ${ }^{[1 \sim 4]}$, 二是晚古生代活动大陆边缘 ${ }^{[5 ~ 10]}$, 因此“白水江群”倍受研究者们的关注. 笔者同项目 组人员在 “白水江群”大堡组灰岩块体中发现晚古生 代生物化石, 为重新厘定南秦岭“白水江群”的时代 和性质提供了重要的证据.

\section{1 区域地质概况}

“白水江群”分布于陕西略阳-甘肃康县以北地区, 在大地构造上位于秦岭造山带西南部, 扬子地台与
秦岭造山带结合部位, 前人称之为“白水系”[11]. 陕西 区域地质调查队在《成县幅》地质填图时命名为“白 水江群”, 划分为大河店组、舟曲组、迭部组和大堡 组(图 1). 在“白水江群” 以北为晚古生代弧前盆 地 ${ }^{[6,7,12]}$ 和三叠纪残余洋盆 ${ }^{[13]}$; 南为勉略混杂带 ${ }^{[14]}$ 、古 生代横丹群弧前盆地和碧口群岛弧火山岩系 ${ }^{[15,16]}$; 向西隔成县盆地与白龙江群相接 ${ }^{[11]}$; 向东与石泉-洋 县一带的弧前增生楔相连 ${ }^{[5]}$.

“大堡组”位于“白水江群”南部, 分布于康县大堡略阳白石沟地区, 南以沈家园-白石沟断裂为界与勉略混杂带相连 ${ }^{[14]}$, 主要由碎屑岩、灰岩块体、硅质岩 块体和火山岩块体组成. 前人认为 “大堡组”属于扬 子被动大陆边缘 ${ }^{[2 \sim 4}$, 将其与成县盆地以西的“白龙 江群”相对比, 时代定为志留纪 ${ }^{[11]}$; 甘肃省区域地质 调查大队在康县大堡乡朱家坝一带深灰色硅质板

英文引用格式: Wang T, Wang Z Q, Yan Z, et al. Discovery of late Paleozoic fossils in tectonic blocks of the Dabao Formation in the South Qinling Orogenic Belt and their significance. Sci China Earth Sci, 2011, 54: 975-981, doi: 10.1007/s11430-011-4183-4 


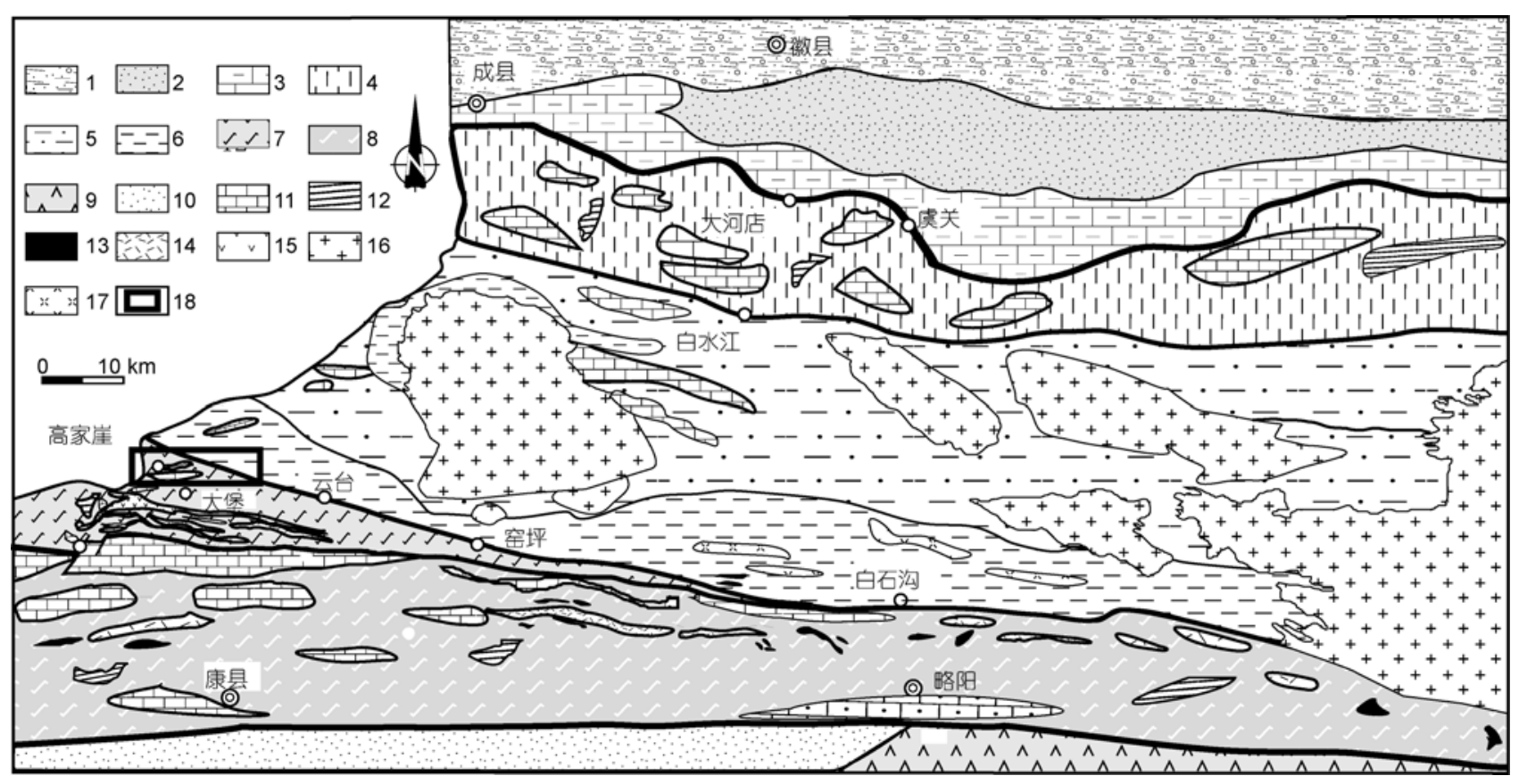

图 1 南秦岭“白水江群”区域地质简图

1. 三叠系; 2. 二叠-石炭系; 3. 泥盆系; 4. 大河店组; 5. 舟曲组; 6. 迭部组; 7. 大堡组; 8. 三河口群; 9. 碧口群; 10. 横丹群; 11. 灰岩; 12. 硅 质岩; 13. 超基性岩; 14. 辉长岩; 15. 火山岩; 16. 花岗岩; 17. 基性岩脉; 18. 图 2 位置

岩中采到晚奥陶世五峰期笔石化石 Paraortnograptus $\mathrm{sp}$. 等 ${ }^{[17]}$, 将其从 “白水江群” 中划分出来命名为奥陶 系大堡组; 王涛等 ${ }^{[9]}$ 在康县大堡炭硅质泥岩中发现二 叠纪放射虫; 间全人等 ${ }^{[18]}$ 在 “大堡组”铁镁质岩中获 得锆石 SHRIMP U-Pb 年龄为 $(800 \pm 22) \mathrm{Ma}$; 王涛 ${ }^{[10]}$ 在“大堡组”基性火山岩块中获得锆石 SHRIMP U-Pb 年龄为 455 和 $677 \mathrm{Ma}$. 本文通过详细的野外地质调 查和剖面的测制, 在“大堡组”灰岩块体中发现了中 泥盆世牙形石和珊瑚等化石，推断“大堡组”形成时 代为晚古生代.

\section{2 岩石组成}

“大堡组”主要由深灰-灰黑色泥岩、泥质粉砂岩 和薄层灰岩以及基性和超基性的火山岩、凝灰岩、灰 岩和硅质岩块体组成, 岩石发生了较强烈变形和低 级变质作用. 岩块裹于碎屑岩基质之中, 或呈断层接 触关系，如硅质岩块体和灰岩块体呈不同大小裹于 泥岩或粉砂岩之中(图 2(a)和(c)), 或者与泥岩或粉砂 岩呈断层接触关系(图 2(b)和(d)). 在基质中, 深灰色 粉砂岩呈薄层状, 厚约 1 3 cm, 内部发育微细的平
行层理, 走向上不连续, 呈透镜状; 深灰-灰黑色泥 岩分布最广, 为薄层状, 最厚的约 $5 \mathrm{~cm}$, 一般层厚为 $2 \mathrm{~cm}$, 走向上延伸较好; 在泥岩和粉砂岩间夹有透镜 状薄层灰岩和炭硅质泥岩. 在区域上“白水江群”中 的舟曲组主要由海底扇的中扇组成, 发育鲍马序列 的 $\mathrm{A}$ 或 $\mathrm{B}$ 段、 $\mathrm{C}$ 和 $\mathrm{D}$ 段, 迭部组由海底扇的外扇组 成, 发育鲍马序列的 C, D 和 $\mathrm{E}$ 段, “大堡组”发育泥岩 和泥质粉砂岩, 为深海和半深海沉积物 ${ }^{[10]}$, 相当于 Mutti 和 Ricci ${ }^{[19]}$ 提出的海底扇沉积 $\mathrm{G}$ 相, 为深海盆地 相环境 ${ }^{[20]}$.

在大堡地区出露的灰岩以构造岩块的形式分布 于灰黑色泥岩和泥质粉砂岩之中, 大小不一, 从几厘 米到上百米. 其中在高家崖出露的混杂岩主要由灰 黑色泥岩、粉砂岩和灰岩块体组成, 灰岩与黑色泥岩 呈断层接触关系位于其上或裹于其中(图 3). 灰岩块 体受到早期构造变形和重结晶作用, 呈扁平椭球体 杂乱地分散在黑色泥岩和细砂岩之中(图 2(c)和 4). 灰岩块体为浅灰-灰白色的角砾灰岩和生物碎屑灰岩, 呈块状构造，偶见层理，表现为再沉积的特征. 在灰 岩块体中含有丰富的珊瑚和海百合茎等化石(图 5(a) 和(b)), 这些化石主要以生物碎片形式成堆出现, 相 

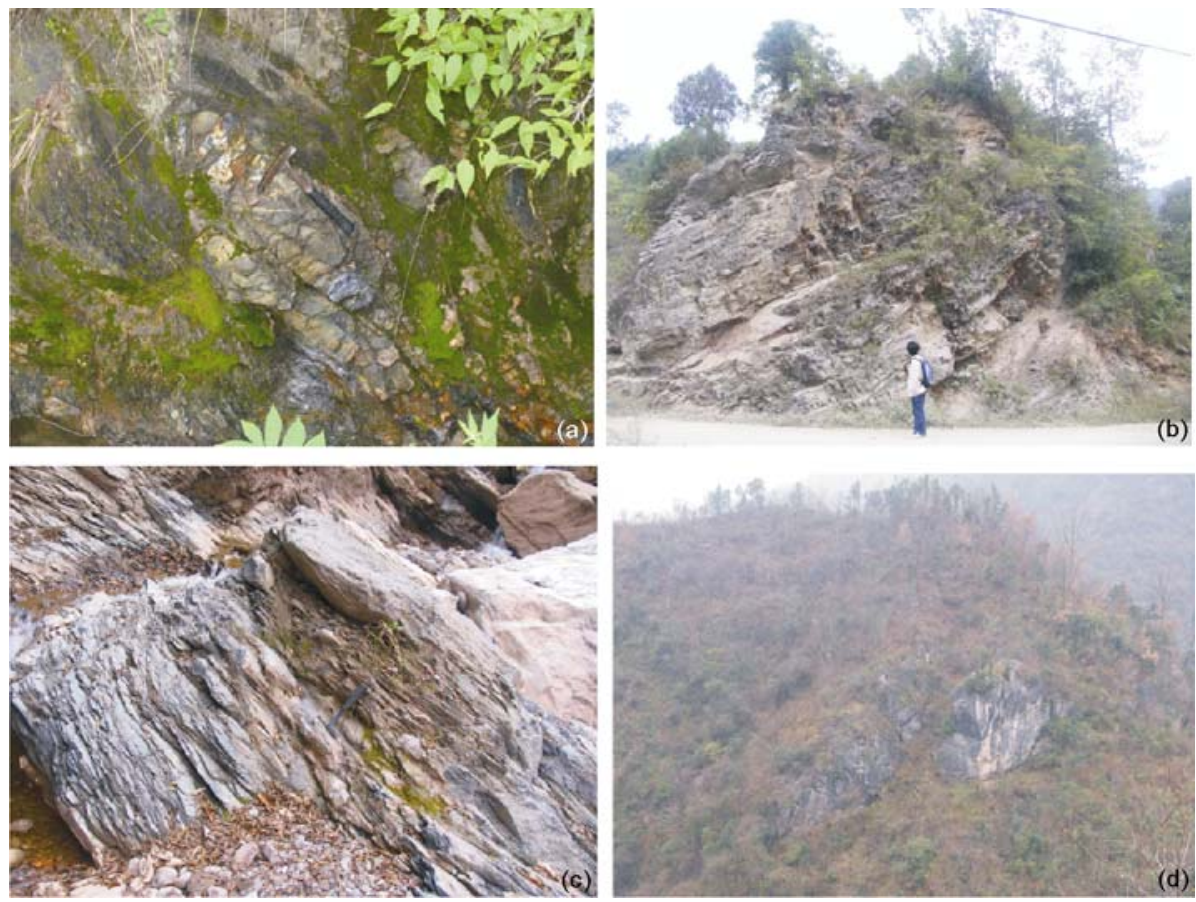

图 2 大堡组中构造岩块的野外照片

(a) 裹于泥岩之中的硅质岩块体; (b) 硅质岩块体; (c) 裹于泥岩中的灰岩块体; (d) 灰岩块体

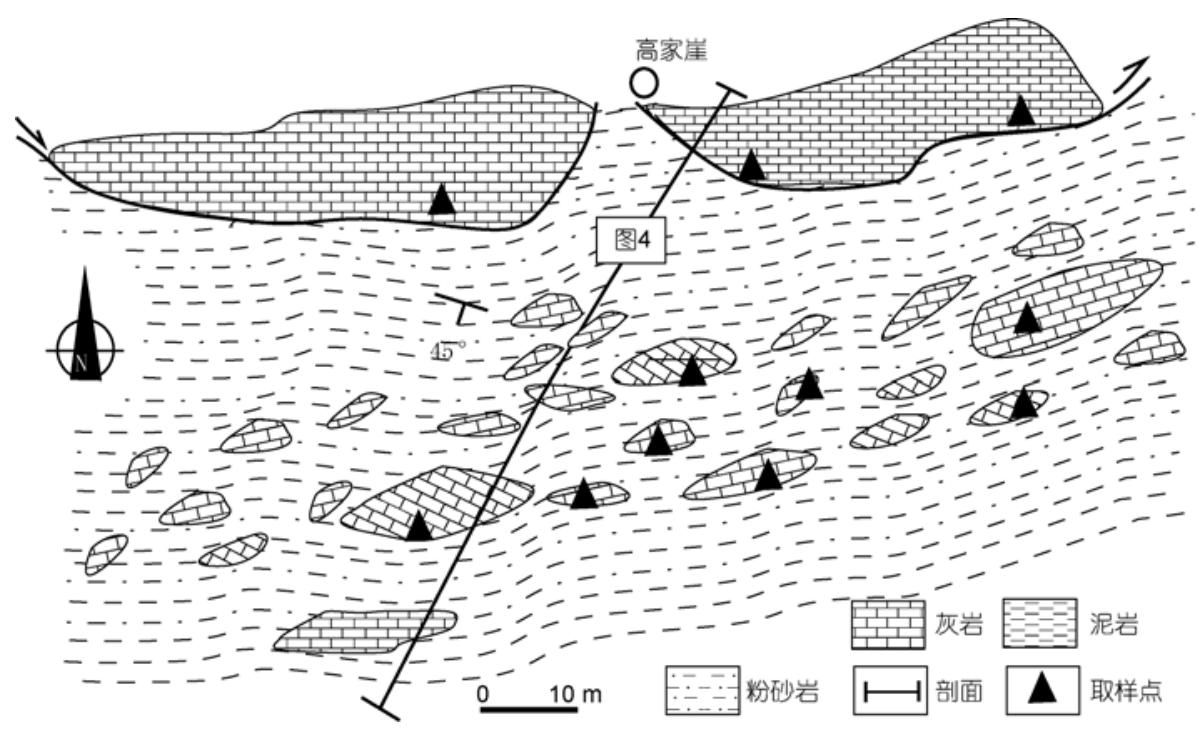

图 3 高家崖地区泥岩和粉砂岩中的灰岩块体

互叠置、无规则排列. 由于灰岩发生了变形和重结晶 作用，导致保存化石的完整性较差.

\section{3 化石组合及其时代}

在大堡组中, 对分布在泥岩和粉砂岩之上和裹
于其间的灰岩块体进行了化石取样(图 3). 在样品处 理过程中, 首先将其进行磨片, 然后在显微镜下观察 化石种类和进行显微照相. 在灰岩薄片中发现了珊 瑚、层孔虫和海百合茎等化石(图 5(c) (h))，这些化石 由长安大学汪明洲教授鉴定. 牙形石化石的分离和 鉴定由长安大学王瑶培副教授进行, 经过碎样、酸 


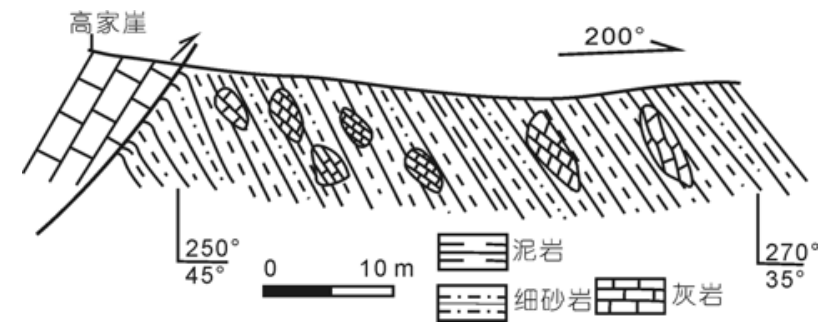

图 4 高家崖地层剖面图

解、洗样和挑样等过程, 在样品中分离出牙形石和海 百合茎等化石(图 6), 这些化石的电子扫描由中国地 质科学院地质研究所大陆动力学实验室陈方远研究 员处理.

在编号为 $\mathrm{Gd} 1, \mathrm{Gd} 3, \mathrm{Gd} 5, \mathrm{Gd} 6, \mathrm{Gd} 7$ 和 $\mathrm{Gd} 9$ 的灰 岩样品中发现尖珊瑚 Charactophyllum sp.(图 5(c)), 枝星珊瑚 Dendrostella sp.(图 5(d)), 枝孔珊瑚 Cladopora sp.(图 5(e)), 双孔层孔虫 Amphipora sp.(图 5(f)), 珊瑚、皮壳层状海绵形水螅类和海百合茎等化 石碎屑(图 5(g)), 小型薄壳腕足和海百合茎等生物碎 屑(图 5(h)).

以上在薄片中观察到的生物碎片, 经汪明洲教 授鉴定其埋藏时代应归为泥盆纪, 埋藏环境应为海 相, 并根据尖珊瑚、枝星珊瑚和双孔层孔虫的存在, 将其埋藏时代归于中泥盆世.

在编号为 $\mathrm{Gd} 1, \mathrm{Gd} 6, \mathrm{Gd} 8$ 和 $\mathrm{Gd} 10$ 的样品中分离 出牙形石化石碎片, 共计 4 个, 包括 2 属 1 种, 分别 为 Ligonodina sp., Icriodus culicellus 和 Icriodus sp. 尽 管该类化石在数量上有一定的局限, 但是在确定地 层时代上有重要的代表性, 非常具有划分时代的意 义. 其中 Ligonodina sp. 属于锄牙形石属(图 6(a)), 由 于化石保存不完整, 不能确定其种. 该化石在贵州长 顺代化和惠永王佑地区上泥盆统代化组有相似的属 出现 ${ }^{[21]}$, 在甘肃省靖远地区石炭系靖远组也发现过 此化石 ${ }^{[22]}$; 贝牙形石(未定种)(Icriodus sp.)(图 6(c)和 (d))在贵州普安罐子窝组 ${ }^{[21]}$ 和新疆北部布龙果儿地区 上泥盆统洪古勒楞组都有发现 ${ }^{[23]}$; 而 Icriodus culicellus (图 6(b)) 在比利时见于 I. fusiformis-I.

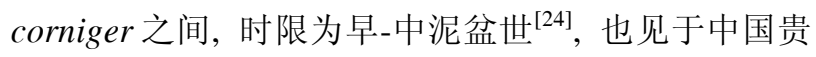
州普安地区中泥盆统罐子窑组 ${ }^{[25]}$.

综合以上的牙形石、珊瑚和层孔虫等化石时代分 析, 表明灰岩块体形成时代为中泥盆世.

\section{4 大地构造意义}

现代大洋地质调查和深海钻探已证实, 在环太 平洋北部和北美西部 ${ }^{[26-28]}$ 、中美洲加勒比地区 ${ }^{[29]}$ 以 及日本等地区发现了众多的海山(洋岛)及其大洋高 原 ${ }^{[30]}$, 并具有一定的结构特征. 张海清等 ${ }^{[31]}$ 结合国 内外资料, 对现代和古代的海山(洋岛)的沉积特征进 行了总结, 认为其具有玄武岩基底和覆盖其上的远 洋沉积物构成的二元结构特征. 蔡雄飞等 ${ }^{[32]}$ 认为海 山或洋岛通常具有洋岛型火山岩基底和碳酸盐岩盖 层的双层结构. 海洋地质调查描述了 Horizon 海山的 地层结构, 上部为钙质沉积物, 下部沉积物富集放射 虫, 基底为玄武岩. Fujioka 等 ${ }^{[33]}$ 对西太平洋日本列岛 附近的海山调查揭示, 当海山接近俯冲消减带时, 导 致海山及其碳酸盐岩盖层发生岩崩、坍塌, 部分未消 减的物质以构造岩块的形式保存在深海沉积物中. 由此可见, 在俯冲-碰撞造山过程中, 海山或洋岛物 质不能被完整地保存, 通常被肢解以构造岩块的形 式保存在基质中 ${ }^{[34]}$.

在康县大堡地区，岩石组合及其空间展布特征 表明, 分布在泥岩和粉砂岩基质中的构造岩块, 包括 浅灰-灰色生物碎屑灰岩、灰绿色变玄武岩、凝灰岩 和炭硅质板岩, 具有现代海山或洋岛组合特征. 其中 的火山岩块体在岩石地球化学上表现为高 $\mathrm{TiO}_{2}$ 和典 型洋岛玄武岩的微量元素特征, 获得锆石 SHRIMP $\mathrm{U}-\mathrm{Pb}$ 年龄为晚新元古代 $(778 \sim 667 \mathrm{Ma})$ 和晚奥陶世

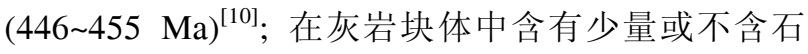
英碎屑颗粒，保存有中泥盆世的珊瑚、海百合茎、牙 形石和层孔虫等海相生物碎屑, 表明其形成于比较 开阔的远离陆源的海相环境 ${ }^{[31]}$, 在炭硅质板岩中含 奥陶纪笔石化石 ${ }^{[17]}$, 因此, 这些岩石块体在形成环境 和形成时代上都具有与现代海山(洋岛)相似的特征.

在大堡地区混杂岩带中分布的构造岩块可能来 源于当大洋发生俯冲消减时, 洋岛或海山及其上部 的灰岩和硅质岩发生坍塌, 部分物质发生消减进入 到地幔中, 少部分物质包括火山岩、灰岩以及深海沉 积物被肢解以构造岩块形式保存在碎屑岩基质中, 但是因后期的构造作用，彼此之间相隔较远. 在大堡 地区东部西乡-石泉增生混杂岩带中也发育洋岛和海 山组合 ${ }^{[5]}$, 在南部紧密相连的勉-略蛇绿混杂岩带中 包含有大量的蛇纹岩块体 (古洋壳残片) 以及洋岛型 拉斑玄武岩块和碱性玄武岩块体 ${ }^{[35]}$, 由此表明大堡 

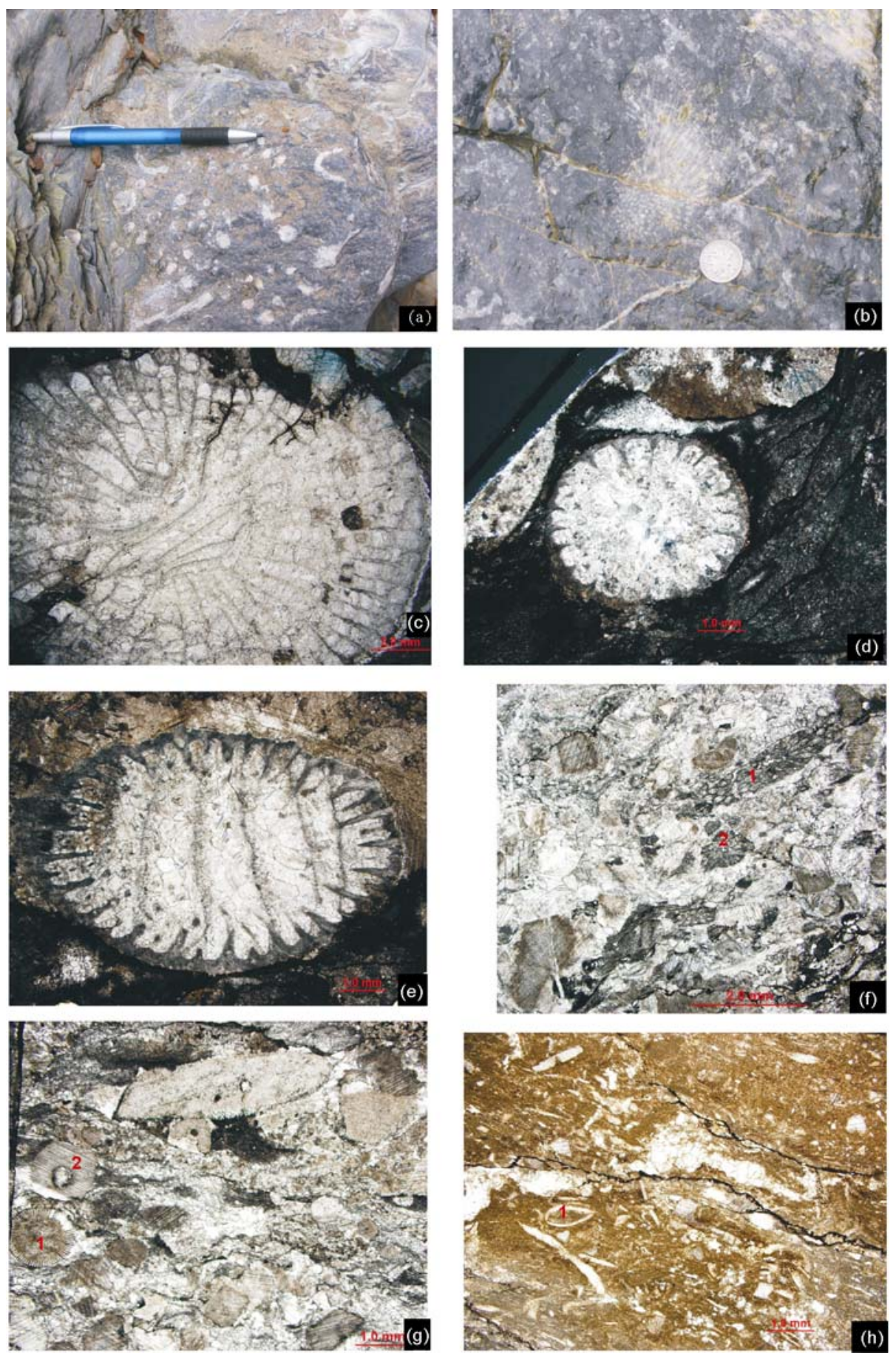

图 5 灰岩块体及其化石

(a) 灰岩块体中的化石; (b) 灰岩块体中的珊瑚化石; (c) 尖栅珊瑚; (d) 枝星珊瑚; (e) 枝孔珊瑚; (f) 层孔虫(1 和 2); (g) 珊瑚(1), 海百合茎(2) 和皮壳层状绵形水螅类化石碎屑; (h) 小型薄壳腕足(1)和海百合茎等化石碎屑

混杂岩、西乡-石泉混杂岩和勉-略蛇绿混杂岩带共同 组成了南秦岭增生混杂岩带.
“大堡组”由碎屑岩基质和岩块组成，时代跨度 较大, 陕西区调队在 1:20 万《成县幅》地质填图中 

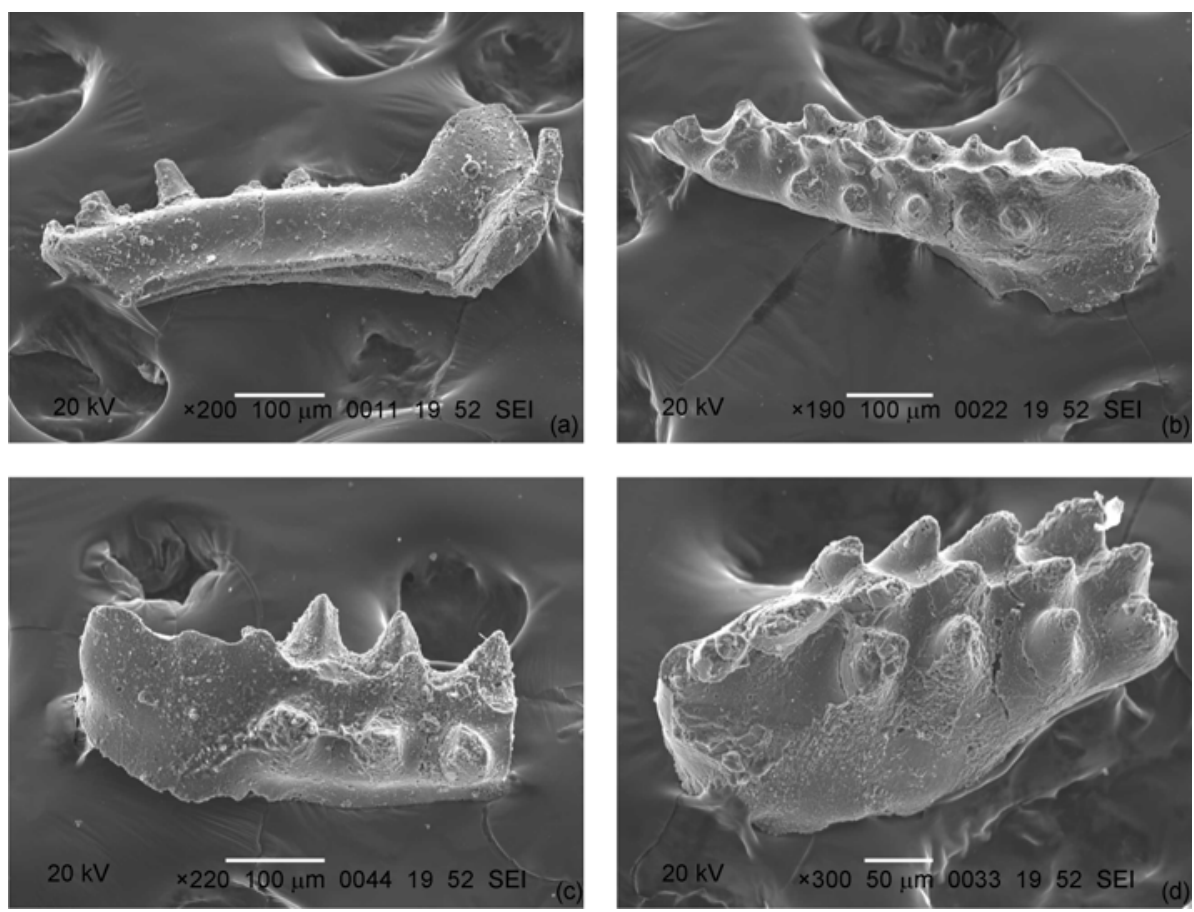

图 6 灰岩块体中的牙形石化石

(a) Ligonodina sp.; (b) Icriodus culicellus; (c), (d) Icriodus sp.

在灰岩块体中发现了中-晚志留世珊瑚和腹足等化石; 朱正永 ${ }^{[17]}$ 在炭硅质岩块体中发现了奥陶纪笔石化石; 王涛 ${ }^{[10]}$ 获得火山岩块体的形成时代为新元古代和奥 陶纪; 间全人等 ${ }^{[18]}$ 获得铁镁质岩的锆石 SHRIMP $\mathrm{U}-\mathrm{Pb}$ 年龄为 $800 \mathrm{Ma}$, 结合本次所发现的中泥盆世珊 瑚和牙形石，表明“大堡组”中构造岩块的形成时限 为新元古代-晚古生代. 王涛等 ${ }^{[9]}$ 在“大堡组”王家集 地区含有灰岩、硅质岩和火山岩块体的炭硅质泥岩中 发现了二叠纪的放射虫, 表明“大堡组”基质的形成 时代可能为二叠纪或者更新. 在区域上, “大堡组”与 东部的西乡-石泉晚古生代弧前增生混杂岩相连 ${ }^{[5]}$, 与南部晚古生代勉-略蛇绿混杂岩带紧密相邻, 北为 晚古生代弧前盆地 ${ }^{[6,7,36]}$, 这些特征与日本列岛和苏 门达腊增生混杂带相当 ${ }^{[37 \sim 41]}$, 从而揭示了所谓的“大 堡组”是在晚古生代由不同岩性和不同时代的构造岩
块组成的增生混杂带.

\section{5 结论}

（1）在南秦岭大堡地区灰岩块体中新发现了中 泥盆世的珊瑚、牙形石和层孔虫等化石，结合早期的 研究成果，表明“大堡组”是由碎屑岩基质和不同性 质、不同时代的岩石块体组成的增生混杂带, 最终形 成于晚古生代或早中生代.

(2) 在“大堡组”中分布的灰岩、硅质岩和洋岛玄 武岩块体，在空间分布、岩石组成和形成时代上具有 洋岛或海山组合特征. 当秦岭古大洋发生俯冲消减 时, 这些洋岛或海山被肢解, 大部分物质发生了消 减, 少数物质以构造岩块的形式保存在增生混杂带 中.

致谢在成文过程中得到中国地质科学院地质研究所姜春发和高联达研究员、纪战胜副研究员以及北京大学刘树文 教授的帮助. 在野外工作中得到陕西地质调查研究院何建社高级工程师、西安矿产地质研究所陈隽路研究员 和北京大学李秋根博士的帮助, 若名评审人和编辑提出了建设性意见, 在此表示衰心的感谢. 
1 Mattauer M, Matte P H, Malavieille J, et al. Tectonics of the Qinling Belt: Build-up and evolution of eastern Asia. Nature, 1985, 317: 496-500

2 张国伟, 梅志超, 李桃红. 秦岭造山带的南部古被动大陆边缘. 见: 张国伟, 等, 主编. 秦岭造山带的形成及其演化. 西安: 西北大 学出版社, 1988. 86-98

3 王清晨, 孙枢, 李继亮, 等. 秦岭的大地构造演化. 地质科学, 1989, 24: 129-142

4 任纪舜, 张正坤, 牛宝贵, 等. 论秦岭造山带. 见: 叶连俊, 钱祥麟, 张国伟, 主编. 秦岭造山带学术讨论会论文选集. 西安: 西北大 学出版社, 1991. 99-110

5 王宗起, 陈海泓, 郝杰. 南秦岭晚古生代-三叠纪弧前增生楔的初步认识. 见: 陈海泓, 等, 主编. 中国碰撞造山带研究. 北京: 海洋 出版社, 1999. 100-113

6 王宗起, 王涛, 间臻, 等. 秦岭晚古生代弧前增生的背驰型盆地体系. 地质通报, 2002, 21: 456-464

7 Yan Z, Wang Z Q, Wang T, et al. Provenance and tectonic setting of clastic deposits in the Devonian Xicheng basin, Qinling Orogen, Central China. J Sediment Res, 2006, 76: 557-574

8 王涛, 王宗起, 间全人, 等. 西秦岭南缘康县-留坝一带白水江群碎屑岩的地球化学特征及构造环境. 地质通报, 2006, 25: 730-736

9 王涛, 王宗起, 姜春发, 等. 西秦岭南缘白水江群晚古生代微体化石的发现及其地质意义. 地球科学与环境学报, 2007, 29: 120-125

10 王涛. 南秦岭增生杂岩带构造岩石组合及其形成过程. 博士学位论文. 北京: 中国地质科学院, 2008. 1-80

11 叶连俊, 关士聪. 甘肃中南部地质志. 地质专报(甲种本), 1944, (19): 1-25

12 Yan Z, Wang Z Q, Wang T, et al. Tectonic setting of Devonian sediments in the Qinling Orogen: Constraints from detrital modes and geochemistry of clastic rocks. Acta Petrol Sin, 2007, 23: 1023-1042

13 姜春发, 朱志直, 孔凡宗. 留风关复理石. 地质学报, 1979, 53: 203-218

14 李春昱, 刘仰文, 朱宝清, 等. 秦岭及祁连山构造发展史. 见: 国际交流地质学术论文集: 区域构造, 地质力学. 北京: 地质出版社, 1978. 174-187

15 陶洪祥, 何恢亚, 王全庆, 等. 扬子板块北缘构造演化史. 西安: 西北大学出版社, 1993. 1-137

16 间全人, 王宗起, Hanson A D, 等. 南秦岭横丹群浊积岩系一一晚古生代发育于扬子板块被动陆缘上的弧前盆地充填物. 地质通报, 2002, 21: 495-500

17 朱正永. 西秦岭南坡的奥陶系. 甘肃地质, 1986, 5: 63-76

18 间全人, 王宗起, 间臻, 等. 秦岭勉略构造混杂带康县-勉县段蛇绿岩块-铁美质岩块的 SHRIMP 年代及其意义. 地质论评, 2007, 53: $755-764$

19 Mutti E, Ricci L F. Turbidites of the northern Apennines: Introduction to facies analysis. Int Geol Rev, 1972, 20: $125-166$

20 Howell D G, Normark W R. Sedimentology of submarine fans. In: Scholle P A, Spearing D R, eds. Sandstone Depositional Environments. Am Assoc Petrol Geol Mem, 1982, 31: 365-404

21 成都地质矿产研究所. 西南地区古生物图册：微体古生物分册. 北京：地质出版社, 1983. 307-308, 438-439

22 王志浩, 王成源. 甘肃靖远石炭纪靖远组的牙形石. 古生物学报, 1983, 22: 437-446

23 赵治信, 张桂芝, 肖继南. 新疆古生代地层及牙形石. 北京: 石油工业出版社, 2000. 145-148

24 Johnson J G, Klapper G, Elrick M. Devonian transgressive-regressive cycles and biostratigraphy, northern Antelope Range, Nevada: Establishment of reference horizons for global cycles. Palaios, 1996, 11: 3-14

25 熊剑飞. 贵州普安罐子窑泥盆纪牙形类生物地层及其沉积环境初析. 贵州地质, 1987, 1: 41-50

26 Watkins R, Flory R A. Island arc sedimentation in the Middle Devonian Kennett Formation, Eastern Klamath Mountains, California. J Geol, 1986, 94: 753-761

27 Soja C M. Island arc carbonates from the Silurian Heceta Formation of southeastern Alaska (Alexander Terrane). J Sediment Petrol, 1990, 60: $235-249$

28 Soja C M. Geological notes: Potential contributions of ancient oceanic islands to evolutionary theory. J Geol, 1992, 100: 125-134

29 Larue D K, Smith A L, Schellekens J H. Oceanic island arc stratigraphy in the Caribbean region: Don't it take for granite. Sediment Geol, 1991, 74: 289-308

30 Wakita K, Metcalfe I. Ocean plate stratigraphy in East and Southeast Asia. J Asian Earth Sci, 2005, 24: 697-702

31 张海清, 孙晓猛, 陈先兵. 洋岛、海山碳酸盐岩的沉积特征及其古地理意义. 地质科技情报, 1997, 16: 29-33

32 蔡雄飞, 蔡海否, 刘德民. 造山带洋岛混杂岩系地层序列和研究意义. 海洋地质动态, 2006, 22: 9-11

33 Fujioka K, Taira A, Kobayashi K, et al. 6000 Meters Deep: A Trip to the Japanese Trenches-Photographic Records of the Nautile Dives in the Japanese Subduction Zones. Tokyo: University of Tokyo Press, 1988. 1-150 
34 Seale M P, Graham G M. "Oman exotics" - Oceanic carbonate buildups associated with the early stages of continental rifting. Geology, 1982, 10: 43-49

35 赖绍聪, 张国伟, 裴先治, 等. 南秦岭康县-琵琶寺南坪构造混杂带蛇绿岩与洋岛火山岩地球化学及其大地构造意义. 中国科学: 地 球科学, 2003, 33: 10-19

36 间臻, 王宗起, 王涛, 等. 秦岭造山带泥盆系形成构造环境: 来自碎屑岩组成和地球化学方面的约束. 岩石学报, 2007, 23: 1023-1042

37 Moore G F, Curray J R, Emmel F J. Sedimentation in Sunda trench and forearc region. Geol Soc Landon Spec Publ, 1982, 10: 245-248

38 Ichikawa K, Maruyanma S, Furuoda F. Accreted ocean material in Japan. Tectonophysics, 1990, 181: 179-205

39 Taira A, Katto J, Tashiro M, et al. The Shimanto belt in Shikoku, Japan—Evolution of Cretaceous to Miocene accretionary prism. Mod Geol, 1988, 12: 5-46

40 Kimura G, Rozhdestvenskity S, Okumura K, et al. Mode of mixture of oceanic fragments and terrigenous trench fill in an accretionary complex: Example from southern Sakhalin. Tectonophysics, 1992, 202: 361-374

41 Von Huene R, Pecher I A, Gutscher M A. Development of the accretionary prism along Peru and material flux after subduction of Nazca Ridge. Tectonics, 1996, 15: 19-33 